УДК $82.081+82: 81$

DOI: $10.17223 / 24099554 / 14 / 10$

\title{
В.Н. Карпухина
}

\section{ГЕНДЕРНЫЙ АСПЕКТ ОБРАЗА АЛТАЯ В ПРОИЗВЕДЕНИЯХ Г.Д. ГРЕБЕНЩИКОВА}

\begin{abstract}
Рассмотрены гендерные характеристики образа Алтая в художественных и публицистических текстах Г.Д. Гребенщикова. В качестве материала исследования выступают очерки Гребенщиикова "Алтайская Русь», "Моя Сибирь», сказка "Хан-Алтай» на русском и английском языках. Образ субъекта-рассказчика соотносится с представляемым в данных текстах локусом с точки зрения гендерологии. Имагологические характеристики гендерной идентичности образа Алтая в текстах Г.Д. Гребенщикова указывают на соединение субъективной, эмочиональной и объективной, философско-аналитической традиций нарратива в данных текстах об Алтае.

Ключевые слова: образ Алтая, Г.Д. Гребенщииков, гендерные характеристики.
\end{abstract}

Образ Алтая в художественных и публицистических произведениях писателей конца XIX - начала XX в. рассматривался достаточно подробно с историко-литературных позиций [1-3], в структурносемиотическом и культурологическом аспектах [4-6]. В некоторых недавних публикациях гендерные особенности образа Алтая осмысляются как достаточно спорные [5. С. 46]. Имагологические характеристики гендерной идентичности образа Алтая позволяют, с нашей точки зрения, выявить в художественных и публицистических текстах Г.Д. Гребенщикова соотнесенность рассказчика, alter ego автора, персонифицированного с помощью местоимения первого лица и представляемого в данных текстах локуса (ср. исследование alter ego как имагологического объекта в нарративной структуре «Писем русского путешественника» Н.М. Карамзина в работе: [7]).

Гендерная отнесенность образа Алтая связана с традиционной, патриархальной андроцентричной языковой картиной мира. В подобном андроцентричном образе мира (см. о соотнесенности поня- 
тий «образ мира» и «картина мира» [8]) способы языкового выражения «контролируются доминирующей группой», а реальность «менее влиятельных групп» не получает репрезентации, как считают Эдвин и Ширли Арденер - достаточно радикально настроенные исследователи роли гендера в функционировании языка в культуре [9. С. 9].

Маскулинная природа Алтая - «Духа Гор» - закреплена в алтайском фольклоре, связанном с воплощением Алтая в «Белом Бурхане и его друге Ойроте» [10]. Символически данное маскулинное воплощение Алтая отражено в текстах Г.Д. Гребенщикова в образе Хана-Алтая, реминисценции к живописным и прозаическим текстам Г.И. Чороса-Гуркина (подробнее см.: [5. С. 46; 11. С. 423]):

Пастух - простой Алтай-кижи, и Чулышман-богатырь - река, и ХанОйрот - пророк, и сам великий Хан-Алтай - Ульгень - все в единой песне сливаются, когда утро встает. Все согласным хором единый гимн поют, гимн вечной жизни и Владыке светлых звезд [12]; Песня Бахсы вместе с гудением домбры журчит уже без слов, как одинокий горный ручей. И Бахса поет иную, лучшую сказку - песнь Хану-Алтаю [11. С. 437].

Представляется абсолютно не случайным, что данный маскулинный образ Хана-Алтая ассоциативно связан у Гребенщикова с темой текущей воды (реки, ручья) и звучащей песни, славящей Алтай (гимн вечной жизни). И сам маскулинный Хан-Алтай, и Хан-Ойрот, и мужское воплощение реки (Чульишман-богатырь), и пастух, и шаман Бахса наделены голосом, способны петь и, таким образом, участвовать в коммуникации с богами и силами природы. Представляет интерес, однако, что в автоперепереводах текстов («Му Siberia», «Khan-Altai») Гребенщиков использует нормативный для английского языка вариант местоимения среднего рода it при референциальных отсылках к существительному Altai:

"Altai - the prayer for Thy mercy - deserves it!"

"Then, descend its steps, drain the earth of the ocean, plant a beautiful garden upon it. When it blooms, I shall come to see it" [14. P. 6].

В патриархальном, андроцентричном образе мира маскулинный образ Хана-Алтая представлен с помощью традиционных когнитивных метафор МУЖЧИНА - ВОИН, МУЖЧИНА - СОЗИДАТЕЛЬ, МУЖЧИНА - ПЕВЕЦ. С точки зрения Дж. Лакоффа и М. Джонсона, 
«метафора... освещает определенные стороны нашего опыта. Метафоры также могут создавать для нас реальность, в частности социальную реальность» [15. Р. 156]. Когнитивные метафоры МУЖЧИНА - ВОИН и МУЖЧИНА - СОЗИДАТЕЛЬ могут быть определенЫ как часть метафорического комплекса СИЛА (ср. [9. С. 116]). Г.Д. Гребенщиков, следуя традиции живописных текстов Г.И. Чороса-Гуркина, достаточно широко использует подобные метафорыолицетворения в своих публицистических и художественных текстах:

Ты стоишь, Алтай, выше туч и звезд. ...На седой главе твоей сияет вечный свет. На каменной груди твоей истоки вечной любви - живая вода [12].

Алтайцы часто напевают свои импровизации, посвященные Алтаю, который как прекрасную страну они особенно остро чувствуют и любят. Они часто изображают его как богатыря и хана, который, снаряжаясь в поход,

О шестидесяти шести пуговицах надевает золоту курму (курма верхняя одежда),

О девяноста девяти пуговицах надевает черный панцирь,

Опоясывает колчан, из которого стрелы торчат, как оголенный лес,

Берет в руки копье, похожее на голую лесину,

В стремя ногами вступает и, изогнувшись в три угла,

Выезжает в путь - Алтай - Бучан - Богатырь [11. С. 391].

Рассказчик в рассматриваемых текстах Гребенщикова описывает внутреннее пространство семиосферы Алтая. Самоописание такого типа пространства «подразумевает местоимение первого лица. ... Это пространство определяется как “наше”, “свое”, “культурное”, “безопасное", “гармонически организованное"» [16. С. 257]. Противостоящая «хаосу», чужому и враждебному пространству, описываемая «сказочная», «мистериальная» семиосфера отделена от внешнего мира линией алтайских гор:

И, конечно, надежда на то, что спящие хребты Алтая - окаменелые богатыри - скоро встанут и явят истинное лицо алтайского народа, все еще ласкает сердце скромного алтай-кижи [11. С. 413].

В публицистических текстах Гребенщикова рассказчик подчеркнуто объективен, передавая фольклорную метафору АЛТАЙ - БОГА- 
ТЫРЬ сначала с помощью несобственно-прямой речи (Они часто изображают его как богатыря и хана), а чуть позже и с помощью прямого цитирования пересказываемого алтайского эпоса (Bыезжает в путь - Алтай - Бучан - Богатырь). В художественном тексте сказки «Хан-Алтай» рассказчик уже предельно эмоционален и субъективен, он сам вступает в прямую коммуникацию с описываемым богатыремАлтаем (Tbl стоишь, Алтай, выше туч и звезд). Это связано с постижением духовной вертикали, восхождением рассказчика к женскому воплощению Алтая - его главе: Высоко ушла в небо в жемчужной короне глава твоя, Алтай, великая Белуха - царица земли! [12].

Гармоничное соединение мужского и женского начал в образе Алтая возникает при восприятии и осмыслении рассказчиком красоты гор: «Здесь же, около деревни Саушки, на полях стоит скала Фараон, или Египетский царь с царицей: величественное сочетание в камне двух характерных образов - мужского и женского» [11. С. 397]. Референциальное обозначение Белухи - царицы Алтая, у которой «чистый лик, чело в венце облаков, могучие плечи - два белых крыла», - производится в текстах Гребенщикова всегда с помощью местоимения она / Она:

И торжественно прозвучал голос Агафона, остановившегося на обрыве.

- А Ее видишь?

Я взглянул через долину прямо в даль на север и ничего не видел, кроме белого, чуть заснеженного облаками, северного небосклона... Но когда поднял глаза выше, то увидел ровно проведенную косую линию, резко разделявшую белое от голубого.

- Это только лишь крыло Ее...- сказал Агафон, и я почуял, что он слово Ее произнес значительно, с заглавной буквой. Только тут я понял и увидел, что принятое мною за небосклон - было частью чего-то волшебно-величавого... [13].

Тот же прием используется Гребенщиковым и при автопереводах публицистических и художественных текстов на английский язык: при референциальных отсылках к существительным гора Белуха / Белуха, вопреки правилам английского языка, используется местоимение she / She:

"It is only Her wing," said Agaphon and I felt that the word Her he pronounced with significance, with a capital letter. ...I see both Her white wings, 
I see both Her heads, those same, those same which long, long ago in my reveries seemed to be the blue wings spread over the magic castle [14. P. 9, 16].

Если в текстах Н.К. Рериха иногда встречается «несогласованность» в роде существительного Белуха и его определений («Белуха, эта Сумеру Азии, стоит белоснежным свидетелем прошлого и поручителем будущего» [10. С. 238]), то в текстах Гребенщикова закрепленность грамматической категории женского рода подчеркивается метафорическим олицетворением Белухи: она - «...корона могучего царя Алтая, находится в стране заоблачной и очень редко сбрасывает с себя пушистую фату туманов; родительница белых чудесных вод; королева азиатских гор» [11. С. 335, 342, 426].

Обретение гармонии с горной природой Алтая происходит для рассказчика очерка Гребенщикова «Сказка-быль» (из книги «Моя Сибирь») в момент преодоления пространственной вертикали, восхождения к вершине Белухи. В данном случае автором соблюдаются традиции русской романтической монтанистики, переосмысленные в рамках модернистского текста [17]. С одной стороны, рассказчик выступает в качестве объективного наблюдателя за своим спутником, молчаливым старовером Агафоном:

...Без грусти я прощался с Ней с последней высоты, которую мы одолели для нашего обратного пути. Без грусти, но с торжественною клятвой всегда носить ее в себе, как символ достижений. Она лежала на лиловых крыльях своего подножия во всей блистательной и лучезарной наготе. Агафон снял шапку, конфузливо, тайком перекрестился, отвернулся и молчал. Я знаю - он почуял Бога и трепетно переживал величие минуты [13].

С другой стороны, рассказчик ощущает гармоническое единение с великолепием гор и мифологизирует женское воплощение Алтая:

...И в то же время вся Она, казалось, плыла на сонме облаков. Точно это была сама царица мира, которая, раскинув перед синею безоблачною высотой небес свои объятия, в нежном томлении ожидала своего божественного жениха. И чуялось, что вот он скоро на своем заоблачном коне покажется над горизонтами в причудливых доспехах победителя-богатыря. И тогда начнется новая жизнь, еще не знаемая человеком - сказка-быль [13]. 
Подобная мифологизация Белухи делает ее не просто ключевым образом Алтая, но и его архаическим символом. Он уже «не принадлежит какому-либо одному синхронному срезу культуры - он всегда пронзает этот срез по вертикали, приходя из прошлого и уходя в будущее» [16. С. 241]. Маскулинное воплощение образа Алтая, Хан-Алтай, оказывается в рассмотренных публицистических и художественных текстах Гребенщикова «образом-реминисценцией». Подлинным воплощением Алтая становится мощный архаический образ-символ царицы Алтая, «королевы азиатских гор» Белухи, которая создает для рассказчика и его спутников «духовную вертикаль» мира.

\section{Литература}

1. Юдалевич М.И. Алтай в художественной литературе // Инструктивнометодический бюллетень. Барнаул, 1953. № 30. Вопросы краеведения. С. 109123.

2. Алтай в трудах ученых и путешественников XVIII - начала XX веков: в 4 т. Барнаул: Алт. краев. универс. науч. б-ка им. В.Я. Шишкова, 2005-2014.

3. Образ Алтая в русской литературе XIX-XX вв. Антология: в 5 т. / под общ. ред. А.И. Куляпина. Барнаул: ООО Издательский дом «Барнаул», 2012. T. 2. $392 \mathrm{c}$.

4. Алтайский текст в русской культуре: сб. науч. ст. Барнаул: Изд-во Алт. ун-та, 2002-2017. Вып. 1-7.

5. Куляпин А.И. Образ Алтая в рассказе В. Бианки «Она» // Филология и человек. 2019. № 2. С. 45-56.

6. Богумил T.A. «Алтайский текст» и литература Алтая: к определению понятий // Филология и человек. 2017. № 4. С. 155-163.

7. Лебедева О.Б. Alter ego как имагологический объект: нарративная структура «Писем русского путешественника» Н.М. Карамзина в свете национальной повествовательной традиции // Имагология и компаративистика. 2015. № 1 (3). C. $5-28$.

8. Янушкевич А.С. От картины мира к образу мира: история становления имагологического текста в русской словесной культуре // Имагология и компаративистика. 2014. № 2. С. 5-16.

9. Гендер в британской и американской лингвокультурах / под общей ред. Е.С. Гриценко. М.: Флинта; Наука, 2011. 220 с.

10. Рерих Н.К. Алтай // Алтай - Гималаи. М.: Мысль, 1974. С. 238-247.

11. Гребенщиков Г.Д. Избранные произведения: в 2 т. Томск: Сибирика, 2004. T. 2. $600 \mathrm{c}$. 
12. Гребенщиков Г.Д. Хан-Алтай. URL: http://az.lib.ru/g/grebenshikow_g d/text 6 khan-altay.shtml

13. Гребенщиков Г. Сказка-быль (Из книги «Алтай - жемчужина Сибири»). URL: http://grebensch.narod.ru/

14. Grebenstchikoff G. Мy Siberia. Рукопись, машинопись (на английском языке). Из материалов личного фонда писателя Г.Д. Гребенщикова. Государственный музей истории литературы, искусства и культуры Алтая, Барнаул. Б. г.

15. Lakoff G., Johnson M. Metaphors We Live By. Chicago: The University of Chicago Press, 2003. 276 p.

16. Лотман Ю.М. Семиосфера. СПб.: Искусство-СПБ, 2000. 704 с.

17. Янушкевич А.С. Русская романтическая монтанистика 1810-1830-х годов как имагологический и компаративистский текст // Имагология и компаративистика. 2015. № 2. С. 5-19.

\section{Gender Aspect of the Image of Altai in George Grebenstchikoff's Works}

Imagologiya $i$ komparativistika - Imagology and Comparative Studies, 2020, 14, pp. 210-218. DOI: 10.17223/24099554/14/10

Viktoriya N. Karpukhina, Altai State University (Barnaul, Russian Federation). E-mail: vkarpuhina@yandex.ru

Keywords: image of Altai, Georgy Grebenstchikov, gender characteristics.

The paper considers gender characteristics of the image of Altai in fiction and publicistic texts by George Grebenstchikoff. The texts under consideration are Grebenstchikoff's essays Altai Rus', My Siberia, the fairy tale Khan-Altai in Russian and in English. The paper aims at revealing the relationship between the narrator and the locus of the texts in terms of the category of gender. Imagological characteristics of the image of Altai gender identity in Grebenstchikoff's texts show the mixture of subjective, emotional, objective, philosophical and analytical narrative traditions in these texts about Altai. Gender identity of the image of Altai is connected to the traditional, patriarchal androcentric worldview, when the way of verbal expression is "controlled by the dominating group", and the reality of the less influential groups is not represented. The masculine nature of Altai, the Mountain Spirit, is shown in the Altai folklore, which is connected to the embodiment of Altai in the images of White Burkhan and his friend Oyrot. Symbolically, this masculine embodiment of Altai exists in George Grebenstchikoff's texts as the image of Khan-Altai, the reminiscence to the art and prosaic works of Grigory Choros-Gurkin. This masculine image of Khan-Altai is associated in Grebenstchikoff's texts with the motifs of running water (a river, a spring) and a song glorifying Altai (a hymn of eternal life). Both the masculine KhanAltai himself as well as Khan-Oirot, the male embodiment of the river (Chulyshmanbogatyr), the shepherd, and the shaman Bakhsa are endowed with a voice, can sing and, thus, participate in the communication with the gods and forces of nature. In selftranslations (My Siberia, Khan-Altai) Grebenstchikoff uses the standard pronoun it while referring to Altai. In the patriarchal, androcentric worldview the masculine im- 
age of Khan-Altai is represented with the traditional cognitive metaphors as A MAN IS A WARRIOR, A MAN IS A CREATOR and A MAN IS A SINGER. The narrator in Grebenstchikoff's texts describes the internal space of Altai semiosphere. Opposite to the "chaos", strange and dangerous space, this "fairy tale", "mysterious" semiosphere is separated from the outer world by the line of the Altai Mountains. In his publicistic texts, Grebenstchikoff's narrator is expressly objective, transferring the folklore metaphor ALTAI - BOGATYR, firstly, with the help of represented speech, and then, with by direct citing from the Altai epic. In the fairy tale Khan-Altai, the narrator is extremely emotional and subjective: he speaks directly to Altai-Bogatyr [Giant Altai], which is related to gaining insight into the spiritual vertical as well as the narrator's ascending to the female embodiment of Altai - its highest peak, Belukha. The reference to Belukha, the queen of Altai, is made in Grebenstchikoff's texts with the help of the pronoun ona / Ona [she / She]. The same strategy is used in the self-translations into English: the author uses the pronoun she / She contrary to the rules of the English grammar. Masculine embodiment of Altai, Khan-Altai, is the reminiscent image in Grebenstchikoff's texts. But the real embodiment of Altai is a strong archaic symbol of the Altai queen, "the queen of Asian mountains", the Belukha, which creates the spiritual stairs of the world for the narrator and his follow-travelers. The writer follows there the traditions of Russian Romantic montanistics, reconsidered in the context of modernism. The masculine embodiment of the Altai image, Khan-Altai, turns out to be a "reminiscence image" in the reviewed Grebenstchikoff's journalistic and literary texts. The true embodiment of Altai is the powerful archaic image-symbol of the queen of Altai, the "queen of the Asian mountains" Belukha, who creates for the narrator and his companions the "spiritual vertical" of the world.

\section{References}

1. Yudalevich, M.I. (1953) Altay v khudozhestvennoy literature [Altai in fiction]. Instruktivno-metodicheskiy byulleten'. 30. pp. 109-123.

2. Kladova, V.P. (ed.) (2005-2014) Altay v trudakh uchenykh i puteshestvennikov $X V I I I$ - nachala XX vekov: $V 4 t$. [Altai in the works of scientists and travelers of the 18th - early 20th centuries: In 4 vols]. Barnaul: Alt. kraev. univers. nauch. b-ka im. V.Ya. Shishkova.

3. Kulyapin, A.I. (ed.) (2012) Obraz Altaya v russkoy literature XIX-XXvv. [The image of Altai in Russian literature of the 19th - 20th centuries]. Vol. 2. Barnaul: Barnaul.

4. Chernyshova, T.V., Grebneva, M.P., Safronova, E.Yu. \& Trubnikova, Yu.V. (eds) (2002-2017) Altayskiy tekst v russkoy kul'ture [The Altai text in Russian culture]. Barnaul: Altai State University.

5. Kulyapin, A.I. (2019) The Image of Altai in the Short Story of V. Bianki "She". Filologiya $i$ chelovek. 2. pp. 45-56. (In Russian). DOI: 10.14258/filichel(2019)2-04

6. Bogumil, T.A. (2017) "Altai Text" and Literature of Altai: to the Definition of Concepts.... Filologiya i chelovek. 4. pp. 155-163. (In Russian). 
7. Lebedeva, O.B. (2015) Alter ego as an object of imagology: the narrative structure of Letters of a Russian Traveler by N.M. Karamzin in the light of the national narrative tradition. Imagologiya i komparativistika - Imagology and Comparative Studies. 1(3). pp. 5-28. (In Russian). DOI: 10.17223/24099554/3/1

8. Yanushkevich, A.S. (2014) From the world picture to the world image: the history of the imagological text formation in Russian literary culture. Imagologiya $i$ komparativistika - Imagology and Comparative Studies. 2. pp. 5-16. (In Russian). DOI: $10.17223 / 24099554 / 2 / 1$

9. Gritsenko, E.S. (ed.) (2011) Gender v britanskoy $i$ amerikanskoy lingvokul'turakh [Gender in British and American Linguocultures]. Moscow: Flinta; Nauka.

10. Roerich, N.K. (1974) Altay - Gimalai [Altai - Himalayas]. Moscow: Mysl'. pp. 238-247.

11. Grebenstchoff, G.D. (2004) Izbrannye proizvedeniya: $v 2 t$. [Selected Works: in 2 vols]. Vol. 2. Tomsk: Sibirika.

12. Grebenstchoff, G.D. (n.d.) Khan-Altay [Khan-Altai]. [Online] Available from: http://az.lib.ru/g/grebenshikow_g_d/text_6_khan-altay.shtml

13. Grebenstchoff, G.D. (n.d.) Skazka-byl' (Iz knigi "Altay - zhemchuzhina Sibi$r i$ ") [Fairy Tale (From the book "Altai - the Pearl of Siberia")]. [Online] Available from: http://grebensch.narod.ru/

14. Grebenstchikoff, G. (n.d.) My Siberia. Rukopis', mashinopis' (na angliyskom yazyke). Iz materialov lichnogo fonda pisatelya G.D. Grebenshchikova [My Siberia. Manuscript, typescript (in English). From the materials of the personal fund of the writer G.D. Grebenstchikoff]. The State Museum of the History of Literature, Art and Culture of Altai, Barnaul.

15. Lakoff, G. \& Johnson, M. (2003) Metaphors We Live By. Chicago: The University of Chicago Press. SPB.

16. Lotman, Yu.M. (2000) Semiosfera [Semiosphere]. St. Petersburg: Iskusstvo-

17. Yanushkevich, A.S. (2015) Mountain art, or the "mountain philosophy" of Russian Romanticism of 1810s-1830s. Imagologiya i komparativistika - Imagology and Comparative Studies. 2. pp. 5-19. (In Russian). DOI: 10.17223/24099554/4/1 